$$
\text { CP552 }
$$

Dust poisan methad for control of boul weeril 


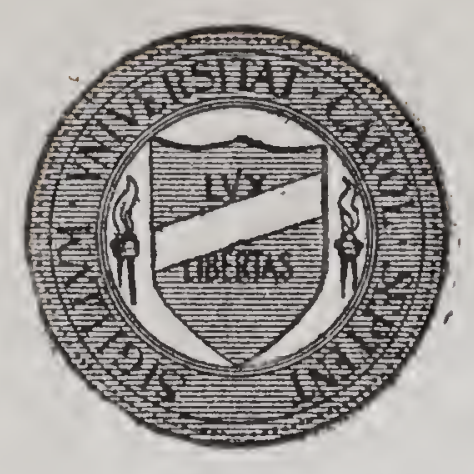

\section{Library}

OF THE

University of North Carolina This book was presented by

\section{Agricultural Extension Service}

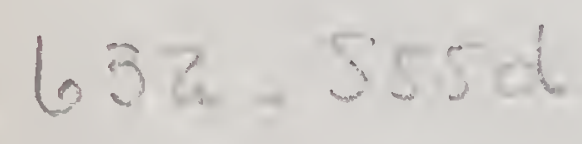

E 


\section{N. C. AGRICULTURAL EXTENSION SERVICE}

$$
\text { OF THE }
$$

STATE COLLEGE AND

STATE DEPARTMENT OF AGRICULTURE AND

U. S. DEPARTMENT OF AGRICULTURE COOPERATING

B. W. KILGORE, DIRECTOR

RALEIGH

\section{DUST-POISON METHOD FOR CONTROL OF BOLL WEEVIL}




\section{CONTENTS}

PAGE

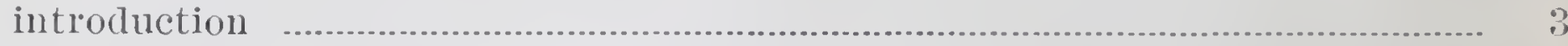

Suggestions for 1923 (Place orders early) ..................................................... 4

Operations in 1922 (Discussion) ……………...................................................... 5

Table of Results—comparative tests (with comment) .......................... 6

Testimony of Farmers (comment) ….........................................................

Chief Difficulties .................................................................................................... 9

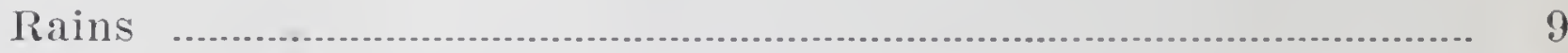

The Night Work

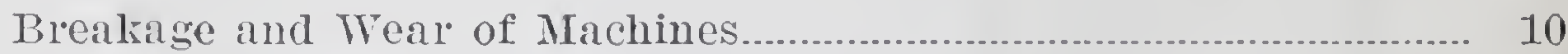

Regulating Amount Poison Per Acre............................................... 10

When to Begin to Dust............................................................................... 10

Machinery for Cotton Dusting (Types) …..................................................... 12

Equipping with Dusting Machines

"How Many Acres Shall I Dust?" ............................................................. 18

Important Points to Observe-Or Avoid...................................................... 18

Dusting Protects But Does Not "Make" a Crop)....................................... 18

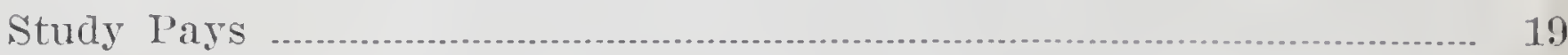

Follow Directions ….......................................................................... 19

Precaution Against Possible Danger........................................................ 19

Don't Be Too Uneasy About Early Weevils............................................... 19

How Arrange Nozzles for Dusting................................................................ 20

How to Poison (The Specific Guiding Directions) …_......................... 20

'Tests by Virginia-Carolina Chemical Company ............................................. 21

(Results of 237 tests in four states)

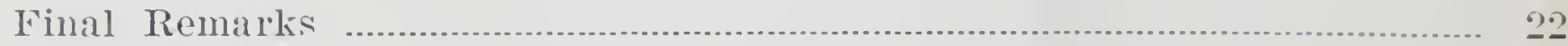




\title{
DUST-POISON METHOD FOR CONTROL OF BOLL WEEVIL
}

\author{
By Franklin Sherman, Chief in Entomology, \\ and \\ W. Bruce Mabee, Assistant in Extension Entomology
}

\section{INTRODUCTION}

The calcium-arsenate dust-poison method for control of the boll weevil was developed mainly by the United States Bureau of Entomology, chiefly by Mr. B. R. Coad and his associates at the Delta Laboratory, Tallulah, La. It is explained in Farmers Bulletin 1262 of United States Department of Agriculture, Washington, D. C., copies of which can be had from Washington or from county agents. It is also explained in Circular 124 of the North Carolina Agricultural Extension Service, Raleigh, N. C., copies of which may be had from county agents or by application to Raleigh.

The present circular shows results secured from this method in southern counties of North Carolina in 1922, in tests directed by the North Carolina Division of Entomology of the North Carolina State College and Department of Agriculture, gives testimony of farmers, discusses the chief difficulties encountered, and is intended to make the matter so plain that any county agent or any studious farmer can proceed with even greater assurance than he could derive from the other two publications already mentioned.

At meeting of Southern Agricultural Workers at Memphis, Tenn., in February, 1923, a committee of experienced men was appointed to summarize, condense and harmonize the facts of boll-weevil poisoning and control problems.

This committee represented veteran experience with boll weevil, with agricultural work, and with the importance of being accurate and safe. The following quotations from their report are important at this time in this connection:

"Of the various methods of control involving the use of poison your committee recommends the calcium arsenate dusting method and the Florida Method. There are no other methods having as yet the sanction of adequate scientific proof. Whether the Florida Method will succeed elsewhere (than Florida) cannot be determined until further studies ............ are made."

"As responsible agencies ........... the agricultural colleges can recommend to the people only such methods as have been fully established by adequate and dependable scientific data."

The report recommended test work by State and Federal agencies of other methods. 
The dust-poison method kills boll weevils and thus protects the squares and bolls, but it does not "make". cotton; lence it does not take the place of the Cultural Methods (advocated from the Division of Agronomy) for securing an early setting of the largest possible crop. Rather the dust-poison method should supplement (to be added to) the Cultural Methods, the two together offering the best chance that we now know to grow a profitable crop of cotton under heavy weevil infestation. Also let us make it clear that in sections (or in fields, or in years) where there are few weevils and light injury, the dust-method will not give its highest returns, and that it does give its highest returns where (or when) the weevil infestation is heaviest.

The dust-poison method appears sound, both in its principles and its results. It has proven good in numerous comparative tests by the United States Bureau of Entomology since 1916; by the experience of experimenters in the several states south of us; by commercial firms; and by our own experience of 1922 .

Despite objections to cost of machines and to the night work, the dust-method stands in our own experience as a profitable method for direct control of boll weevil, and it renders all the greater opportunity of a more certain profit when the Cultural Methods are fully employed. It has been winning its way by definite and indisputably profitable results.

It will pay the farmer to study the method as described in this circular, so that he shall know what to do, when to do it, and how to do it. It is also important that he should not go astray in making wasteful and needless applications of poison in fields where they are not needed, or at times when they are not profitable.

The dust method is recommended more especially for fairly fertile lands; it is not advised to dust a crop which is naturally capable of less than about one-third or one-half bale per acre; there should be the reasonable assurance of a crop worth dusting.

With these suggestions plainly given, we commend the dust-poison method to farmers who will do it carefully.

\section{SUGGESTIONS FOR 1923}

As the dust-poison method pays best under heavy weevil infestation, we do not advise it in all that northern part of the North Carolina cotton area where injury is due to be light in 1923.

The region where we do advise it for 1923 is south of a line drawn from Hickory in Catawba County to Salisbury in Rowan, to (10 miles south of) Raleigh in Wake, to (about 8 miles north of) Washington in Beaufort. All the region south of such a line is due for severe injury in 1923 ; and in the southern and eastern part of this region especially there is every reason to expect that proper dusting will pay well. In all this region the Cultural Methods for early setting of crop should be studiously followed. 
In the region north of the line indicated the injury will probably be heavier to southward and eastward, hence in such sections as Edgecombe, northern Pitt, Martin and eastward there will likely be some fields in which it would be profitable. A year hence (season of 1924) our entire cotton section up to the Virginia state line, will be due for heavy injury, closely approaching the full normal for future years. In the region north of the line the Cultural Methods for early setting of crop should be studiously followed as a preparation for the future, and we advise gathering and burning the squares (if practicable) once a week to middle or end of July.

Order Poison and Machines Early.-There is likely to be a shortage of calcium arsenate during 1923, so it is highly important that those who intend to dust should place orders early for their poison, and the same advice applies (perhaps with less urgency) to machines. Both poisons and machines should be on the farms before June 1st, even though actual dusting might not begin until the latter part of July. Calcium arsenate should be bought at rate of 25 to 30 pounds for each acre which it is intended to dust. Likewise, machines should be ordered according to acreage, making sure not to attempt to dust too large an acreage for the machines you have. We wish to emphasize that care be used to follow the suggestions and directions.

A number of merchants in this state are handling approved machines and calcium arsenate. Consult county agent, or write for information.

\section{OPERATIONS IN 1922}

Farmers are entitled to know the reasons for our confidence in the proper following of the dust-poison method.

In 1922 we undertook to advise and guide those who would use the dust-poison method in our southern counties where injury was due to be severe. Upward of 50 farmers did some dusting. We were in communication with most of them and visited many of the fields. About fifty tons of calcium arsenate was used. At close of the 1922 season we gave all the opportunity to describe their results, experiences and opinions. The replies of those who both dusted and reported are quoted later-no unfavorable ones withheld-we give the entire showing. Some did not report.

Mr. Mabee was located in Scotland County for most of the growing season, and personally followed the work on five farms to the point of securing the comparative yield of dusted and undusted cotton (alongside, on uniform land in same field) culture, fertilization, etc., being the same. In Bladen, county agent R. K. Craven at Clarkton made a similar test on cotton of his own and has furnished us the figures. In Onslow, county agent D. L. Latham has given us similar figures from the work of Dr. L. D. Bryan at Snead's Ferry. These seven cases we present as fair comparative demonstration tests under field conditions. 
The results of these tests, all figured on bases of one acre (though the plots averaged larger than one acre) are shown in the following table:

DEMONSTRATION TESTS, BOLL WEEVIL CONTROL, 1922

Long Staple Cotton

\begin{tabular}{|c|c|c|c|c|c|c|c|}
\hline \multirow{2}{*}{ Name and County } & \multirow{2}{*}{$\begin{array}{l}\text { Times } \\
\text { Dusted }\end{array}$} & \multicolumn{2}{|c|}{$\begin{array}{l}\text { Yield Seed } \\
\text { Cotton per } \\
\text { Acre, Pounds }\end{array}$} & \multicolumn{2}{|c|}{$\begin{array}{l}\text { Gain per } \\
\text { Acre by } \\
\text { Dusting }\end{array}$} & \multirow{2}{*}{$\begin{array}{l}\text { Cost } \\
\text { of } \\
\text { Dust- } \\
\text { ing } \\
\text { per } \\
\text { Acre } \\
\text { for } \\
\text { Season }\end{array}$} & \multirow{2}{*}{$\begin{array}{c}\text { Net } \\
\text { Profit } \\
\text { per } \\
\text { Acre by } \\
\text { Dust- } \\
\text { ing }\end{array}$} \\
\hline & & Dusted & $\begin{array}{c}\text { Not } \\
\text { Dusted }\end{array}$ & $\begin{array}{l}\text { Pounds } \\
\text { Seed } \\
\text { Cotton }\end{array}$ & $\begin{array}{c}\text { Value } \\
.\end{array}$ & & \\
\hline Z. V. Pate, Scotland...... & 6 & 1,883 & 1,481 & 402 & $\$ 48.24$ & $\$ 7.00$ & $\$ 41.24$ \\
\hline
\end{tabular}

Short Staple Cotton

\begin{tabular}{|c|c|c|c|c|c|c|c|}
\hline 1. J. N. Gibson, Scotland -- & 4 & 1,311 & 1,054 & 257 & 24.93 & 2.88 & 22.05 \\
\hline 2. W. N. McKenzie, Scotland & 5 & 1,612 & 1,464 & 148 & 14.22 & 4.75 & 9.47 \\
\hline 3. MeL. Gibson, Scotland & 5 & 1,845 & 1,468 & 377 & 36.53 & 4.13 & 32.40 \\
\hline 4. J. C. Hunsucker, Scotland & 3 & 1,913 & 1,705 & 208 & 20.02 & 3.50 & 16.52 \\
\hline $\begin{array}{l}\text { 5. R. K. Craven, County Agent, Bladen } \\
\text { (own work) }\end{array}$ & 6 & 1,000 & 500 & 500 & 48.42 & 10.92 & 37.50 \\
\hline County Agent Latham) & 6 & 750 & 410 & 340 & 32.78 & 6.20 & 26.58 \\
\hline Average for six short staple tests...- & 5 & 1,405 & 1,100 & 305 & $\$ 29.48$ & $\$ 5.40$ & $\$ 24.08$ \\
\hline
\end{tabular}

Note.-The figures for times dusted, yield of dusted and undusted cotton, gain by dusting, and cost of dusting, are figured from the records of the farmers themselves with Mr. Mabee in all of the Scotland County tests-in the other two cases the figures are from county agent.

The figures on value of gain, and net profit per acre by dusting, are figured on following basis at suggestion of Mr. Frank Parker, Agricultural Statistician : Long staple cotton at 32c. per $1 \mathrm{~b}$. for lint; short staple at 25c. per $1 \mathrm{~b}$. for lint; also that one-third of weight of gain was lint, and two-thirds seed.

We have figured all seed at 2c. per pound, which we believe conservative.

The figures for cost of dusting includes labor and poison on 1922 prices, and also includes an allowance for 'wear on machines except in case of Mr. Craven, who in making liberal allowance for poison says that he thinks the cost as given is sufficient without further allowance for machine, which he says is yet in good condition.

Comment.-The highest gain in pounds of seed cotton is by Mr. Craven in Bladen, who says that his figures, although "round," are very close to exact accuracy; he was under heavy infestation and made heavy applications on account of rains.

The lowest gain is by Mr. McKenzie, whose undusted plat was very narrow, and presumably received some poison while dusting adjoining rows, thus lessening the difference. In another test (separate from ours) his gain was 368 lbs. seed cotton per acre. His average gain for the two tests was therefore 258 lbs. seed cotton per acre.

The highest net profit per acre by dusting is by Mr. Pate, whose cotton was Delta Type long staple. His test is therefore not included in the average at bottom of table, which is for six short-staple tests only. 


\section{TESTIMONY OF OTHER FARMERS}

The testimonials which follow are not so clearly convincing as the results given in the preceding table, because of the lack of definite comparative figures. The season of 1922 was rainy, and we include letter's to show how some were discouraged by the rains, while others were making profitable gains by dusting during the same rainy season.

\section{ANSON COUNTY}

Mrs. Bessie Little, Wadesboro:

"One white tenant dusted about 7 acres with hand-duster, two acres separated by road was dusted three times; says that dusted three times had top cotton while the other did not. It is his opinion that it paid."

Mr. W. C. Hall, manager for Eli Griggs, Wadesboro:

"We think we got some results from dusting. While it rained continually during the dusting period, we picked 21 bales cotton from the 16 acres dusted." (This was in spite of heary infestation in mid-olyly, as shown in our notes.-F. S.)

\section{Mr. Lester Ratliff, Morven:}

"Don't know just what to say about it, as we had so much rain during the time we were trying to use the dust we didn't get a fair test of it. I think we must have gotten some good from it, but the fields we dusted had so many more weevils than the ones we didn't dust that it would be hard to tell."

Mr. L. G. Atkinson, Wadesboro (place 25 miles out farmed by colored tenant): "Had about 16 acres in cotton and used mule-back duster" (Saddle-gun) with rery good results. Could not leave fair undusted plat for comparison, but feel quite sure the operation paid. Dusted four or five times after and during big rains in first of August. Expect to use duster coming season if weevils show up as they did this year. I wish to thank," (etc.)

\section{BLADEN COUNTY}

R. K. Craven, County Agent:

( $S$ ee figures from his own cotton in table on page 6. )

"Mr. James Sterens, Council, N. C., with 50 acres Cleveland cotton estimated that he made $400 \mathrm{lbs}$. more seed cotton per acre by dusting, fire applications, 6 lbs. per acre each time. His brother did not do so well, as he planted another variety cotton."

\section{ONSLOW COUNTY}

Mr. (name withheld), Richlands:

"I did not dust this year. It was too rainy for dusting to pay"

Mr. (name withheld), R. D. 1, Jacksonville:

"I didn't do any dusting. It is useless to dust when it rains every day."

See figures for Dr. I. D. Bryan, Onslow County, in table on page 6, to see what dusting did during that rainy season. 


\section{RICHMOND COUNTY}

\section{Mr. W. H. Barton, County Agent, Rockingham:}

"A marked difference can be seen in the top crop of fields dusted and those not dusted. Those who dusted, so far as I can determine, did not leave undusted plats for comparison."

Mr. L. F. Thomas, Rockingham:

"Did not dust; only a few weevils in spots till about close of opening season. Planted about 6 acres ordinary land and made 4 bales with no dusting. I think that did very well."

\section{Mr. W. N. Everett (Everett Farms), Rockingham:}

"We tried some of the various methods and the dusting method recommended by the Department. While we kept no accurate account of cotton picked from acres so treated, both our superintendent and the writer agree that the methods advocated by your department gave materially better results than any other method used."

\section{SCOTLAND COUNTY}

(See figures in table on page 6 for results other than reported here.)

Mr. H. W. Malloy, Laurinburg:

"One acre not dusted, $700 \mathrm{lbs}$. seed cotton; one acre dusted, $724 \mathrm{lbs}$. seed cotton.

"I might add that this land should not have been dusted, as its normal production is only about 900 lbs. per acre.

"On the rest of the crop which was dusted I feel confident that the dusting paid, and it is my intention to dust all my cotton in 1923 on land which would normally produce as much as 1,200 lbs. seed cotton per acre. Sorry my figures are not more favorable, but I will continue to dust."

(If his dusting was well done, the small gain would indicate that his infestation was light.-F. S.)

H. W. McLaurin, Johns:

"I used the dust on my cotton this season, and am sure it paid well. Am satisfied it increased my crop 15 per cent."

Mr. D. K. McRae, Laurinburg:

"I made enough on a few acres to pay for the machine and the arsenate. On a field of 7 acres we made 7 bales, by four dustings. On 10 acres of long staple cotton we made 8 bales.

"Where we did not dust we made about $1 / 2$ bale per acre. It rained so continuously," (etc.).

Mr. E. S. Gibson, Johns:

"Used dust on 13 acres. This made 12 bales. Another crop (not dusted) of 12 acres made $S$ bales; another of 22 acres made 14 bales; but this difference was not altogether due to dusting, for the land where dusting was done would make more than the other anyway."

Mr. G. G. Mathews, Laurel Hill:

"Made two applications of dust, and while I did not weigh in on the check plat, I am satisfied that it paid me. Arranging to dust our entire acreage next year, and we have it understood with our tenants that they are to apply this poison. Thanking, . . . complimenting," (etc.). 


\section{UNION COUNTY}

Mr. (name withheld), R. D. 1. Monroe:

"I did not dust. The boll weevil got my cotton. Made only 4 bales on 10 acres, where I usually make 10 bales."

Mr. H. C. Boyce, R. D. 5, Monroe:

"I dusted a good deal and am well pleased with results, but did not have any check (undusted) plats. On 11/4 acres dusted three times I got a bale of $475 \mathrm{lbs}$. lint. Dusted as late as August 20. Expect to dust on larger scale in 1923. Wish to thank," (etc.).

\section{COMMENT ON TESTIMONY OF FARMERS}

It will be noticed that while some report that they could not dust on account of rains, yet in the same counties others who persisted made good results by dusting. Also, the results in our table of comparative tests on page 6 show a substantial profit per acre in every case. It would seem that the season would have to be more rainy than 1922 to justify a neglect of dusting. Indeed the general experience elsewhere has been that dusting is most needed, and often gives its highest profits in seasons which are classed as "rainy."

\section{CHIEF DIFFICULTIES}

It is fair that we should frankly recognize the chief difficulties which we encountered.

Rains.-Rains were frequent in season of 1922 , yet the dusting paid well. The treatments gave enough profit so that if one had to give two (or even three) dustings in succession to get one that was fully effective, there might still be a good profit.

Hence we suggest to take a chance on the weather and dust even in the prospect of a rain rather than neglect it after the dusting point is reached. In this matter the grower has the chance to show judgment and skill, and can profit by being prepared to take advantage of every chance. The official weather forecasts may help. While rains did interfere, all our tests were profitable in spite of them. We aimed to dust as the directions say ("How to Poison," pages 20-21), and if a rain threw us out of the schedule we returned to it at the earliest opportunity.

The Night Work.-We did not find this impossible or impracticable. Many farmers (tobacco-growers especially) do night work at certain seasons. Small areas of cotton may be dusted in part of a night. Very large areas may call for all-night work for some men or shifts of partnight each.

It is well to arrange in advance to have a thoroughly competent workman do this work at the start (or do it one's self) and break in others as they learn by observation and by helping. Have at least one extra lantern.

In the hot weather of July and August night work is cooler than day work. 
Breakage and Wear of Machines. - With the horse-machines trouble on this score was severe in hilly and stony fields, where broken links or cogs, wearing of gears, etc., were more or less frequent. We know of two in Anson County whose experience was flatly discouraging on this account. In such fields we believe the tendency will be toward the Hand-guns and Saddle-guns.

A certain amount of mechanical ingenuity is helpful in setting up a machine in first place and in keeping it in working order afterward. The printed directions with a new machine should be noticed. Extra parts most subject to wear should be quickly available. 'The grower and operator should become familiar with the machine, test it out and watch its workings, before the time for actual dusting arrives. There are plenty of farm machines (not to mention autos) which are more complex and difficult than the cotton-dusting machines.

Regulating Amount of Poison Per Acre-Clogging of Pipes, Etc.The general directions are to use " 5 to 7 pounds per acre for each application." While the machines have a device for regulating the flow of dust, yet these are not always accurate, and it is advisable to make a test on a few acres and correct it if needed. Farmers have the tendency to use more poison than necessary; this may be on the side of safety, but it may easily run into needless expense.

A pipe may clog so that its flow of dust is not adequate; a kink, a bit of trash in feeding device, or a "caking" of the dust by moisture at some point. Experience soon helps to prevent or remedy these difficulties. Sheer accidents, such as running a machine into a stump or ditch, may be costly. While the operation is yet new, it is best to entrust it only to reliable workmen.

When to Begin to Dust.-The directions say: "Start poisoning when the weevils have punctured from 10 to 15 per cent of the squares." That time of 10 per cent puncturing (or more) we therefore call the "dusting point," and our experience indicates that it is abundantly worth while for the farmer to know how to determine when this point is reached. And it is quite simple; here it is:

Examine 100 squares in each of 3 to 6 typical spots in the field (300 to 600 squares in all). These spots should be well separated and representative of the field in general. Open the shuck and examine the bud, doing this with squares low on plants as well as in top, examining those large enough to be attractive to weevil (experience will soon teach). Do not pick unpunctured squares, but ones showing the usual pimple-like "puncture" should be picked and put in pocket. Having thus examined 100 squares on one or two rows at the first spot, rou now count the punctured squares in pocket. If there are 15 , write down on your piece of paper "15" for the first spot. Go to the next spot and make similar count and examination ; perhaps here you will find " 27, and write it down. The third spot may show "9," and the fourth may give "11." You then merely average the four counts: $15+27+9+11=62$ (divide by 4 to get arerage) $=15 \frac{1}{2}$ per cent for the four spots, and as this is over 10 per cent, dusting should at once begin. 
It is entirely simple, and any person who has the least aptitude for figuring can become proficient in an hour of actually doing it. Four to six spots in a field of 5 to 10 acres can be adequately examined, and calculation made, in one-half to one hour by one person. If a certain side or end of field is found to be regularly much more heavily infested earlier in season than the rest of the field, that portion may be given an earlier dusting. If the infestation seems reasonably uniform (or with many bad spots) over the whole field, then dust the whole when the general average reaches 10 per cent. But the examination should be fair, including squares low on plants as well as high, as otherwise one may merely deceive one's self.

There is much sentiment for poisoning the first weevils, killing them before the 10 per cent point is reached, etc. Our experience indicates that this may be misleading and is apt to result in waste. To wait until 10 per cent of the squares are punctured does not mean that 10 per cent of the crop is destroyed, for there is normally a surplus of squares. In 1922 there were many fields in our southern counties which had weevils from the time they came out of winter-hiding (late May), yet which did not reach the "dusting point" (of 10 per cent of squares being punctured) until a good crop was well assured; such fields, not dusted at all, often yielded as much as in former years; to have dusted them early apparently would have been wasteful. But there were other fields in which the "dusting point" (of 10 per cent) was reached by middle or" end of July; in such fields those that were well dusted made a full (or nearly) normal crop, and those which were not dusted made much less than a normal crop. Our experience, with many examinations and counts recorded in our notes, indicated over and over again that hundreds of dollars could easily be wasted by needless dusting, and hundreds of dollars gained by dusting when it was needed.

In 1922 in our southern counties the "dusting point" (of 10 per cent) was reached in heavily infested fields from July 12 to August 1, and averaged about July 25 , approximately two months after weevils first appeared in the fields. For two months, with weevils in the fields, we sat tight and saved, as one farmer figuratively remarked: "waiting until we could see the whites of the enemies" eyes before firing." Then, when the "dusting point" (of 10 per" cent) was reached, in late July, we began the dusting, and our results were profitable in every case, as shown in table on page 6 .

If the dusting practice becomes permanently common among our people, undoubtedly this point of when to begin dusting will become more or less fixed by community practice, the more careful farmers setting the pace, and the time to begin may vary from year to year according to severity of infestation. Our effort in 1922 was and our effort in writing these pages is, to point the way safely for the more 
careful farmers. Dusting need not begin on any fixed date; it depends on the weevil infestation, not on the calendar. Gradually approximate calendar dates may come into use.

We readily grant that as the "dusting point" approaches, it is better to begin dusting a little before it is actually reached than to delay too long.

\section{MACHINERY FOR COTTON DUSTING}

There are four general types of cotton dusting machines, adapted to different acreages or conditions. Between makes of machines of the same type there is room for difference of opinion. A number of merchants in the State are handling machines. Consult county agents or farmers who have had good experience, or write us for information.

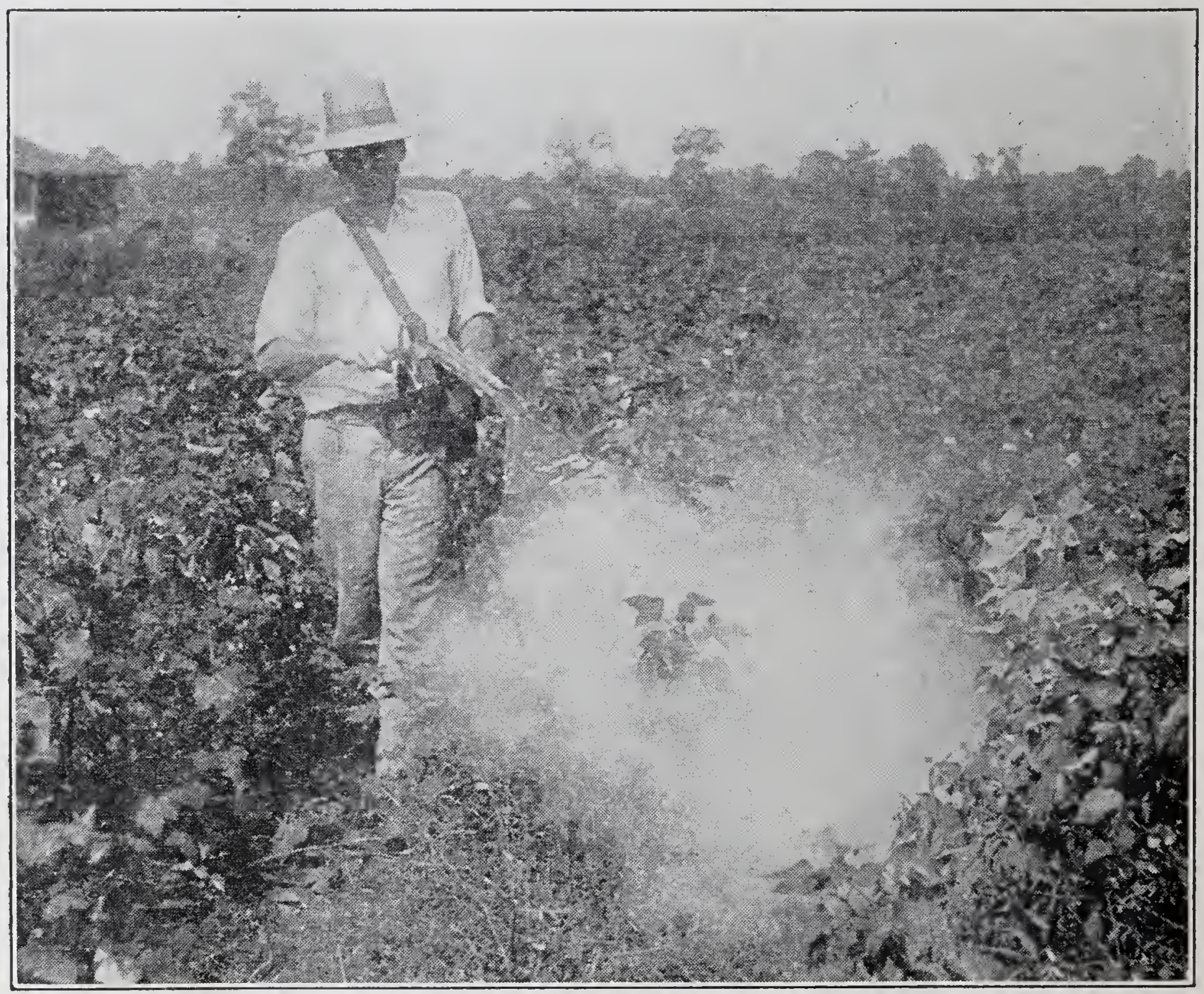

Fig. 1.-Hand gun in operation in cotton field.-(From U. S. Dept. Agr.)

Hand-gun.-Carried by operator, worked by hand, treats one row at time. One machine can take care of 5 to 8 acres of cotton for the season. Better not attempt these on more than 20 to 25 acres. Lasts one to three years according to care and use. Costs from $\$ 12$ to $\$ 20$. (See Fig. 1.)

The Hand-guns are in favor for small acreages, odd patches, short rows, etc., for those of limited means, or for getting preliminary experience first season. One or more may well be used on larger plantings to supplement the larger machines. 


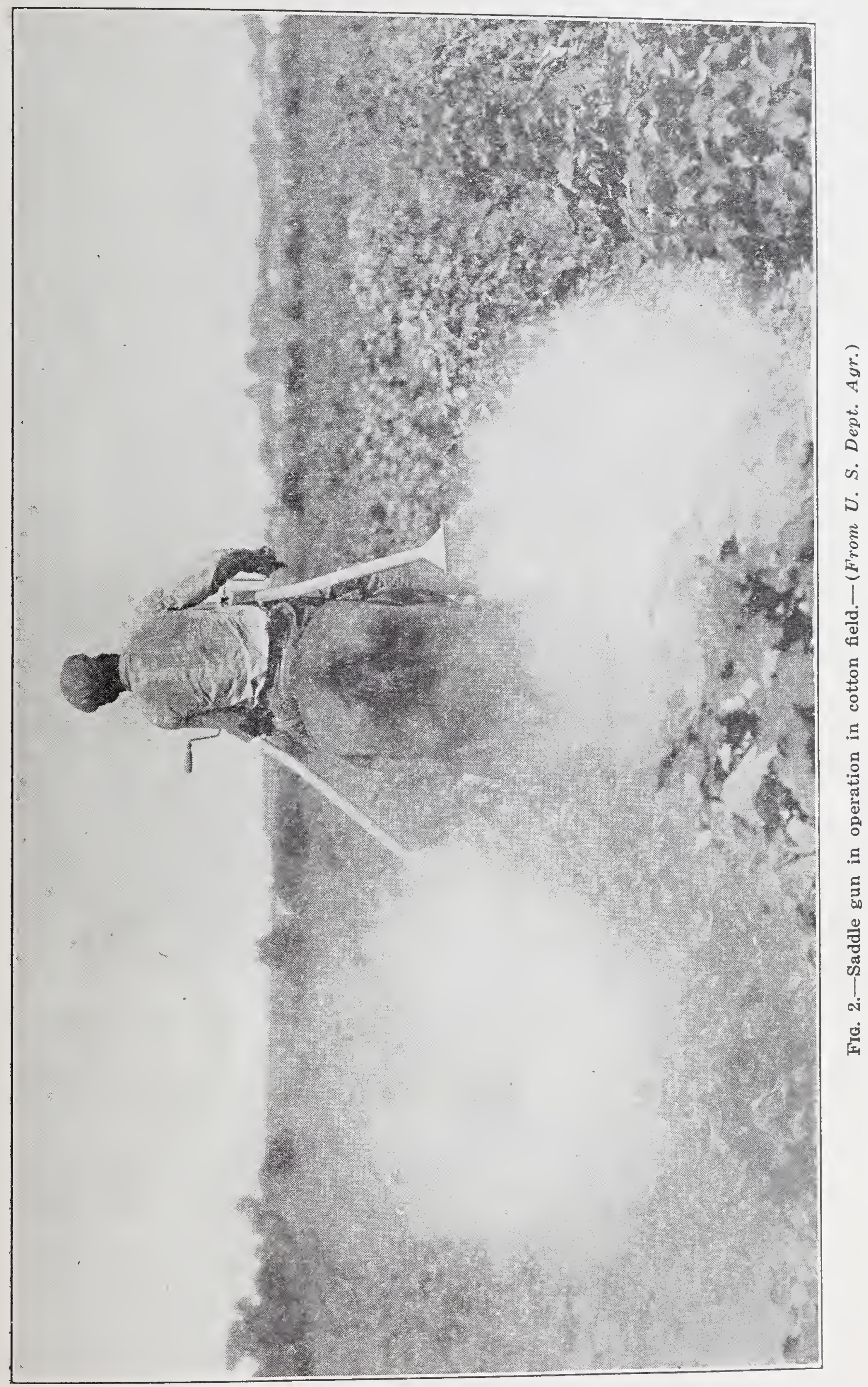


Saddle-gun.-This is a type of duster which is carried on mule-back and operated by rider, treating two rows at time (one each side). One machine can take care of about 50 acres of cotton for the season, and should last 1 to 3 years. Costs around $\$ 50$ or more according to attachments. This type is quite in favor for rough, stumpy, irregular land, with short rows, etc. (See Fig. 2.)

The Saddle-guns seem to be winning their way rapidly, especially for rough, hilly, or wet lands, irregular rows, etc.

One-mule Machine.-Operated by one man and one mule; runs between rows like walking-cultivator on single wheel, which is geared to fan. Treats two rows at time (one each side). One machine can take care of 50 to 60 acres of cotton for the season, and should last 3 to 5 years. Costs around $\$ 100$ to $\$ 125$. (See Fig. 3.)

There are many who faror the One-mule Machines because of their adaptability for rapid work, the fan being driven by the wheel instead of by hand. We expect them to gain in favor more especially in the smoother, more level lands of our eastern counties.

Cart Machine.-Two-wheeled machine, straddles one row, operated by one man (who rides) and drawn by two mules. Treats 3 rows at time. One machine can take care of about 100 acres of cotton for the season, and should last 4 to 6 years. Wheels geared to fan. Costs around $\$ 250$ or more. (See Fig. 4.)

As yet but few of these larger machines have been used in this State. Naturally they are for larger acreages, and better suited to level fields, as in our eastern counties. From what we hear they have given satisfaction.

Equipping with Dusting Machines.-We do not care to here express any preference for particular machines-your own opinion after experience might be different from ours-but we may help you to decide on the type of machines to use. Let us "suppose" several classes of farmers:

(1) Growing 5 acres cotton on one farm.-One Hand-gun should be enough for a case of this kind.

(2) Growing 10 acres cotton on one farm.-Two Hand-guns, which would be cheaper, or one Saddle-gun, which could handle the work more rapidly and with greater certainty.

(3) Growing 20 acres cotton, one farm.-Four, or better five, Handguns might do, but it would be better to have one Saddle-gun, or one One-mule Machine. Might be well to have one Hand-gun (extra) for short rows, odd corners, etc.

(4) Growing 50 acres cotton, one farm.-Either, one Saddle-gun, or preferably one One-nule Machine. We would advise one Hand-gun in addition.

(5) Growing 75 acres cotton, one farm.-Two Saddle-gums, or two Onemule Machines (one might do), or one of each type. A Hand-gun also would be handy.

(6) Growing about 100 acres, one farm.-Either one Cart-machine, or two Saddle-guns or two One-mule Machines, or one Saddle-gun 


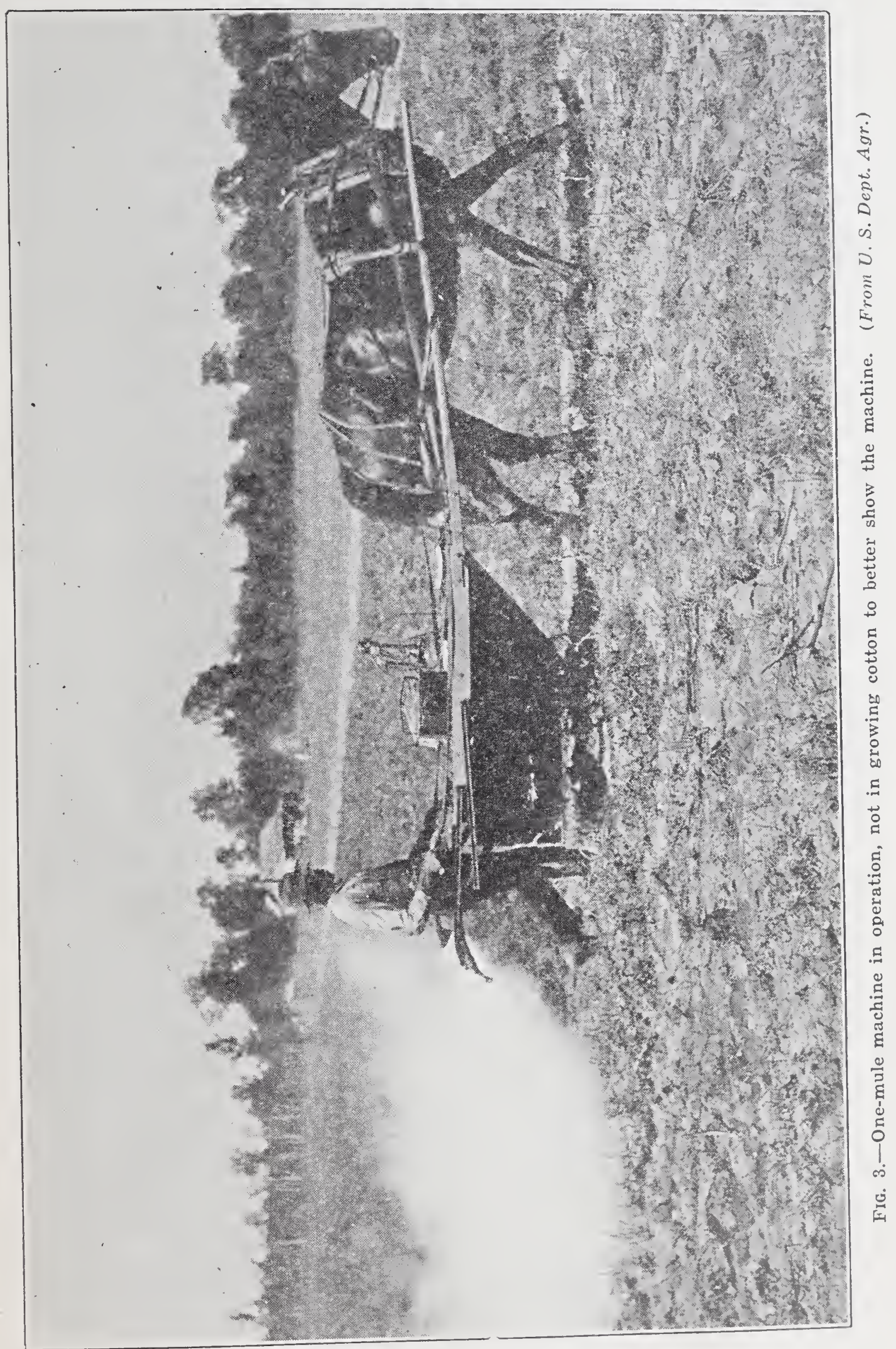


and one One-mule Machine, with also a Hand-gun for odd places, etc. We would incline toward two less expensive machines rather than one more expensive one-your preference may lead to the other decision.

( 7 ) Cotton on several farms. - For a case of this kind we believe it better to equip for each, separately-for there is delay and wear in hauling a machine from farm to farm-one might get good benefit and the other not, or even both might fail of proper benefit. If several farms with small acreage each are close together, one of the larger capacity machines may do for several-but be careful.

We incline to advise one to go conservatively in his first attempts at dusting, furnishing ample machinery for the one or more fields which are to be dusted, even if other fields are left undusted in the first year's experience. Certainly it is not safe to go beyond the capacity of a machine thus we have given the capacity of the One-mule type as 50 to 60 acres for season; if one were to attempt to dust 75 to 100 acres with one One-mule Machine, he almost certainly could not get over the whole at the frequent intervals ( 4 days, preferably) that is desirable at the height of the dusting season, and would perhaps fail of proper result on the whole 100 acres; whereas, if he limited it to its proper capacity of 50 to 60 acres, his result might be highly profitable.

We have mentioned Hand-guns to supplement the larger machines for larger acreages. They are handy for corners, odd rows, stumpy places, or in an emergency when the larger machine might be out of order. But the hand-operated machines are more tiring on the operator and less regular in their delivery of dust (when operator is tired) than the wheel-geared machines. The wheel-geared machines are less expensive in operation (especially on the item of labor cost), though they are more expensive in purchase-price; and in our experience broken links, etc., are often frequent.

While we cannot discuss every condition of farms and acreage, we have tried to go far enough into this detail to show that one should consider carefully how much acreage he will attempt to dust, should order ample machinery for that acreage, and then not attempt greater acreage than the machinery can handle.

And a good general guiding rule is: have enough machinery to get over the acreage in three full night's work. This is the general basis on which we have stated the acreage capacity of the machines: thus, by indicating the capacity of One-mule Machine at 50 to 60 acres, we mean that the machine should dust that acreage in 3 full nights operations (i. e., from 14 to 20 acres per night). Allowing one night for rain or delays, this gets over the entire acreage at four-day intervals.

Of course the acreage covered will depend on the skill and industry of operator, and the rate-of-step of mule, etc. And the number of years that a machine will last will depend on care and use. 


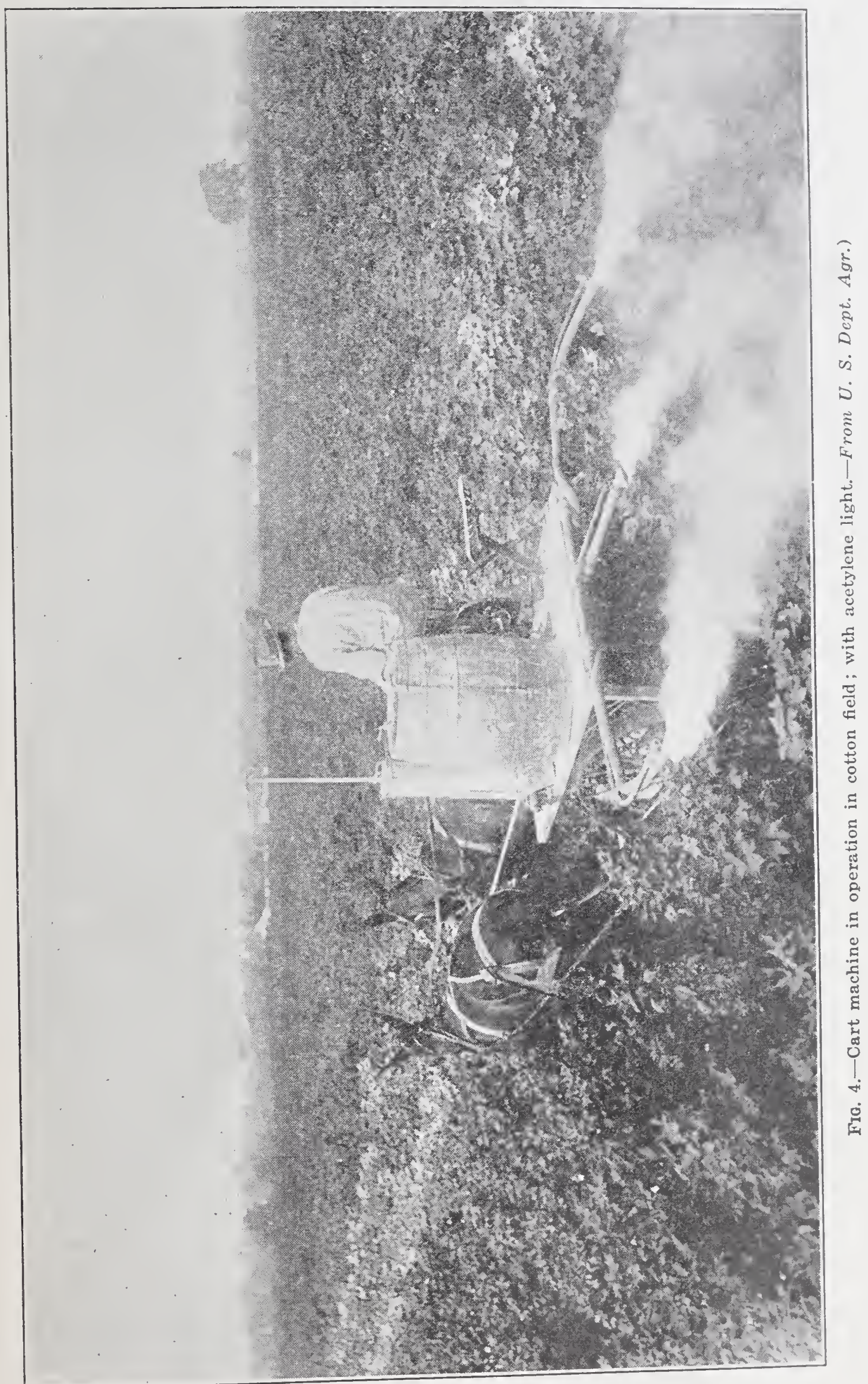




\section{CALCIUM ARsenate (The Poison)}

As this is written, there is prospect of a shortage of this in 1923, and we hope that it will be relieved before 1924. Under a similar but less acute shortage in 1922 our growers who ordered early (March to May) secured what they ordered. This year (1923) we are urging early ordering, and we are informed of many tons (even carloads) already in the State. Whether one wishes to order independently or in coöperation with others, our advice is to place the order without delay. A number of merchants in the State are handling this material. Consult county agent, or write for information. Present prices range from 17 to 21 cents per pound, according to quantity, etc.

'How Much to Order.-We advise ordering 25 to 30 pounds of calcium arsenate for each acre it is intended to dust-the smaller amount will cost less, but the larger amount is safer as allowing for some waste by rains, etc. Thirty pounds would permit of five dustings of 6 lbs. per acre each. Experience indicates that generally the number of dustings needed varies from 3 to 6 -with occasional cases where more than six may be needed, or where less than three may do. If one has poison left over it may be sold, or it is good for another year if kept perfectly dry. The man who must economize to the limit and who may lack confidence in the method, may order a minimum-but he who is proceeding with safe and studious confidence will see the wisdom of having plenty for his needs and then using it at the time when it gives best profit, at proper rate, at proper intervals.

\section{"HOIV MANY ACRES SHALL I DUST?"}

This must depend on your ability and willingness to provide adequate machines and poison-and the ability of your labor organization to handle the work. Those with small acreage and fair means may undertake to dust all their cotton. Those with large acreage, scattered farms, indifferent labor, or limited means, may well prepare to have only one, or a few, of their fields dusted, these to be selected among those workers who are most competent, or whose fields are most infested-and expand their operations in years to follow as experience points the way.

While yet lacking in actual experience, one may well give much thought to having his first dusting properly done ("Do It Right or Not at All"), for all the great body of experience-not only our own, but in other states also - indicates that success lies in having such a plan adequately provided for.

\section{IMPORTANT POINTS TO OBSERVE-OR AVOID}

1. Dusting Protects, but does not "make" a Crop.-Do not imagine that mere "dusting" will make a profitable crop of cotton in spite of boll weevil-it will not. The very best of Cultural Methods for securing the largest possible "setting" of the earliest possible crop are highly important. In the fields where our comparative tests were conducted 
in 1922 ( see table, p. 6) the Cultural Methods were generally good, so that even the undusted cotton gave fair yields; and then, when we applied the dust-poison method, substantial additional profits were secured by the dusting. A late, poor, stunted crop on thin, poor land, carelessly cultivated, might be a losing proposition anyway, and dusting (even if well done) on such a clop might not pay. There should be the reasonable assurance of a crop worth dnsting. It is not advised to dust a crop natnrally capable of less than abont onethird or one-half bale per acre. And of corrse, by good cultural methods many profitable crops are raised without dusting.

2. Study Pays.-We know of no substitnte for intelligent care and proper study in meeting the boll weevil problem. As in any other test, sone have failed in this test, and others have "kept on their feet."

3. Follow Directions.-Give careful heed to the brief explicit directions under "How to Poison," on pages 20-21. These directions are simple, clear and definite; in our experience thus far success lies in following then.

4. Precaution Against Possible Danger.-Althongh about 50 tons of poison was dusted on cotton in North Carolina in 1922, we have not heard of any case of death or sickness (even of farm animals) which was laid to this dust-poison method.

Yet it should be remembered that calcinm arsenate (an innocentlooking white powder) is poisonous. The containers should be kept closed, so the material will not be reached by children or animals. In using the horse-drawn machines put a muzzle on aninal, especially if inclined to nip at plants; however, in all except the hand-gmus, the poison is delivered behind or below both animal and operator so the animal is usually between umpoisoned rows. The operator shonld breathe as little of the dust as possible. After dusting work the horse may be cleaned or curried; and operator should wash, clean finger nails, brush off clothes and (if possible) change garments. With these cautions we have heard of no accidents.

With the several weeks that elapse after last dusting and before picking, the poison disappear's to such extent that after picking the cotton may be grazed.

5. Don't be too Uneasy Abont the Early Weevils.-An anxious grower may easily waste time, poison, and wear of machines in wasteful dustings for early weevils. It is advised to "start poisoning when weevils have punctured 10 to 15 per cent of the squares." Omr experience was that this time arrived (approximately) after middle of July. This threw the main dusting operation into a short season ( 4 to 6 weeks) when the crop needed the protection most.

In case weevils seem to be so abundant before squares begin to form as to puncture a destructive percentage as fast as the squares are well formed, it would then be advisable to make the first application when the cotton starts squaring freely, or about the tine the plants average from 4 to 5 squares each. While this necessity apparently arose muder the heavy spring enrergence of 1922 in some of the states south of us, we did not observe it in North Carolina in the same year.

The "Florida Method" includes a distinct and separate procedure ained at the early weevils-but its adaptation to this State is not yet worked out. 
There was a period of two weeks or more (late June to early July, 1922) when weevils were scarce-this was a natural interval between the over-wintered generation which had died off and the newly bred next generation. This deceived many who thought they already had the weevil under control. The same natural interval occurred where no effort was nude against the early weevils.

Onr profitable result in every case, by waiting until the 10 per cent point was reached, justifies us in advising not to break hastily away from the definite directions. Better to cling to what has proven good until clear tests or contrary experience shall point the way to still more profitable proceedings.

6. How Arrange Nozzles for Delivery of Poison? The Hand Guns deliver the dust obliquely downward, and with them we prefer to hold the nozzle from 6 inches to one foot above or from the plants. The Saddle Guns deliver chiefly downward, and we suggest to have the nozzle about a foot above average height of plants. The larger (wheel-geared) machines deliver downward or horizontal, and we prefer the horizontal delivery to be about 6 inches above average height of plants.

All these details are subject to variation. The essential object is to deliver a uniform cloud which (in the still air with the plants moist) will slowly settle. Our examinations after dusting showed the dust inside (under the bracts) of the squares. It is not desired to have certain leaves or plants receive much heavier coating of dust than others, hence the advantage of not having the nozzles continually dragging on the wet leaves of the plants.

\section{HOW TO POISON (The Specific Guiding Directions)}

(Adapted from U. S. Dept. Agr. Circular 162, by Coad and Cassidy.)

1. Use only pure calcium arsenate in form of dry powder.

2. Apply this only in the dust form.

3. Use only dusting machinery especially constructed for cotton-dusting.

4. Dust only when the air is calm and the plants are moist. This practically means making only night applications.

5. Use about 5 to 7 pounds of calcium arsenate per acre for each application.

6. Start poisoning when the weevils have punctured from 10 to 15 per cent of the squares.

7. Keep the cotton thoroughly dusted until the weevils are under control. This usually means about three applications at rate of one every fourth night.

8. Then stop dusting (poisoning) until the weevils again become abundant.

9. If the weevil again becomes abundant early enough to injure young bolls, make one or two more applications late in the season.

10. If you have a heavy rain within 24 hour's after dusting, repeat the application immediately (or that part of it done within the 24 hours ).

11. Do not expect to eradicate the veevils. Poisoning merely controls them enough to get a full crop, and you can always find weevils in the successfully poisoned field.

12. Keep cotton acreage low and try to increase the yield per acre, as it costs as much to poison one-quarter bale per acre cotton as bale per acre cotton. 
13. If you wish to prove the matter to yourself, leave an occasional fair average part unpoisoned to compare its yield with the adjoining poisoned part.

14. If you intend to poison, get in touch with County Agent, or State officials, or U. S. Delta Laboratory at Tallulah, La., for any special help they may offer.

\section{"DO IT RIGHT OR NOT AT ALL"}

Analysis of Poison. - The calcium arsenate to be used for cotton dusting should analyze as follows: not less than 40 per cent total arsenic pentoxid-not more than 0.75 per cent water-soluble arsenic pentoxiddensity not less than 80 or more than 100 cubic inches per pound.

In former years the United States Department Agriculture made analyses of samples, but this is now impracticable and largely unnecessary, as the manufacturers have the material fairly well standardized.

\section{TESTS BY VIRGINIA-CAROLINA CHEMICAL COMPANY}

\section{Agricultural Service Bureau, A. E. Grantham, Director}

During 1922 this organization supervised tests of the dust-poison method on many farms in North Carolina, South Carolina, Georgia, and Alabama, and in a booklet "Beating the Boll Weevil," issued December, 1922) the results are given for 237 farms where the comparative yields of dusted and (adjoining) undusted cotton were secured. The plan included in each case 5 acres dusted and 5 acres not dusted. In so large a series, over so wide territory (and with such large plots), irregularities in land and infestation were sure to occur-and their notes indicate this. In some of their fields (in North Carolina also) the infestation was light so the gains were small. It is probable also that some of the work was better done, or better timed, than in other cases. Hence wide differences in the details of the results are not surprising. Their general plan was much the same as we advise in the preceding pages.

When we average their results as secured in each state we find the following:

Virginia-Carolina Chemical Company Tests, 1922

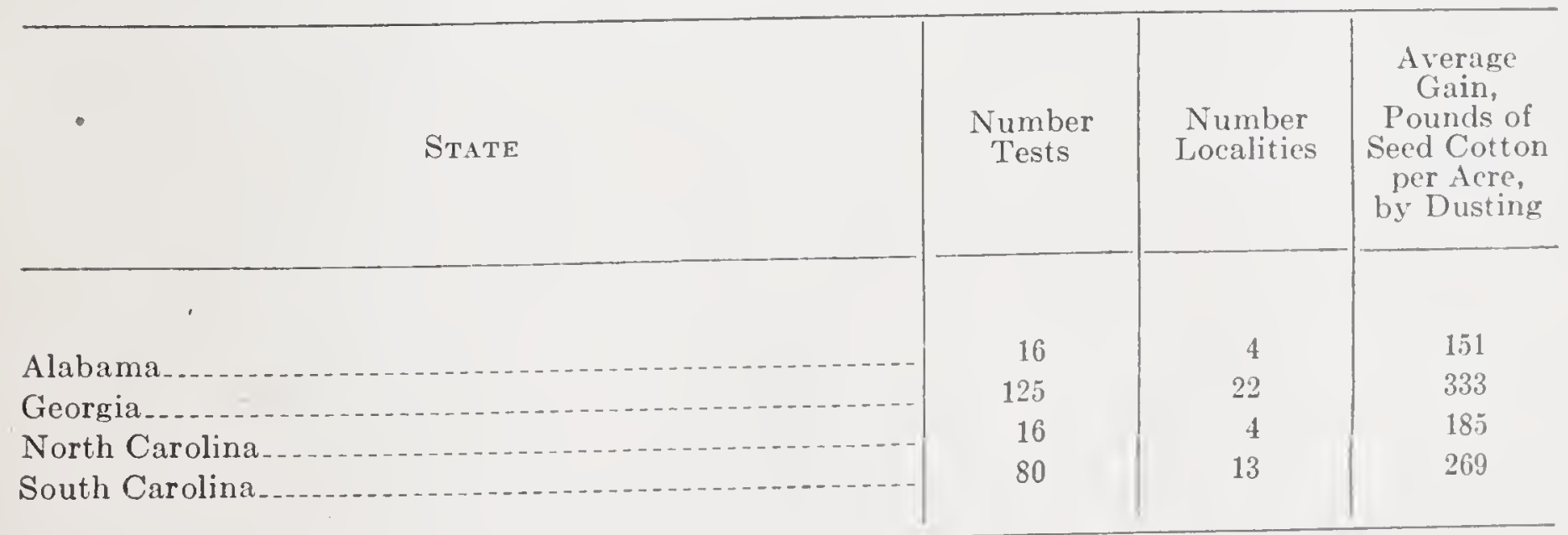


The general average from all 237 tests, figured on basis of one acre, was as follows:

Dusted cotton, lbs. seed cotton per acre $857 \mathrm{lbs}$.

Not dusted, lbs. seed cotton per acre $562 \mathrm{lbs}$.

Gain-lbs. seed cotton per acre, by dusting. $295 \mathrm{lbs}$.

They figure the average cost of dusting at $\$ 7.20$ per acre, and on this basis the 295 lbs. seed cotton gives a substantial net profit above costs.

\section{FINAL REMARKS}

Mr. B. R. Coad, of United States Bureau of Entomology, stationed at Delta Laboratory, Tallulah, La., who has been chiefly instrumental in developing the dust-poison method, has said: "The gains vary widely, but usually average 200 to 400 lbs. seed cotton per acre." An exact average of the two figures he mentions would be $300 \mathrm{lbs}$. It is interesting to note that in our own seven North Carolina tests (in 1922) the average gain was $319 \mathrm{lbs}$. seed cotton per acre (or 305 lbs. per acre for the six short-staple tests only), and that in the 237 tests by the VirginiaCarolina Chemical Company (in 1922) the average gain was 295 lbs. seed cotton per acre.

It therefore seems fair to regard 300 lbs. seed cotton per acre as a good standard gain to hope for from proper dusting when weevils are rather abundant. But it is perhaps best to expect less than we hope for, and a gain of 200 lbs. seed cotton per acre is gratifying. For, while fluctuations in prices vary the case, it is generally true that a gain of 100 lbs. seed cotton per acre will pay the cost of a season's dustingon 1922 prices about 75 lbs. would have done it-we can run into endless calculations on costs and possible prices and possible profits or losses; it is not our place to do this. Our results of 1922 indicate a sound profit from proper employment of the dust-poison method for control of boll weevil. 




\section{Photomount Pamphlet Binder! Gaylord Bros. Makers \\ Syracuse, N. Y. PAT. JAK 21, 1908}

\section{FOR USE ONLY IN}

THE NORTH CAROLINA COLLECTION

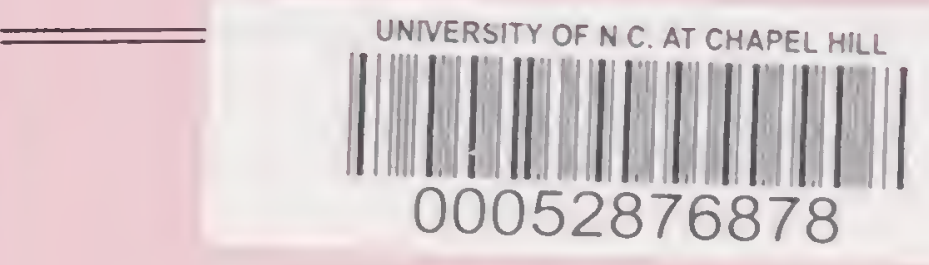


